\title{
FUMONISINS IN CORN CULTIVARS IN THE STATE OF SÃO PAULO
}

\author{
Simone M. Camargos ${ }^{1}$; Lucia M. Valente Soares ${ }^{1 *}$; Eduardo Sawazaki²; \\ Denizart Bolonhezi²; Jairo L. Castro²; Nelson Bortolleto
}
${ }^{1}$ Departamento de Ciência de Alimentos, Faculdade de Engenharia de Alimentos, Universidade Estadual de Campinas, Campinas, SP; ${ }^{2}$ Instituto Agronômico de Campinas, Campinas, SP.

Submitted: March 23, 2000; Returned to authors for corrections: July 03, 2000; Approved: September 20, 2000

\begin{abstract}
Twenty three samples, belonging to 19 corn cultivars with distinct types of germoplasms, endosperm and length of vegetative cycle, were analyzed for fumonisins $B_{1}$ and $B_{2}$. The cultivars were grown in experimental fields in three locations (Votuporanga, Ribeirão Preto and Capão Bonito) within the State of São Paulo, Brazil, during the $97 / 98$ crop. All samples were contaminated with fumonisins with concentrations ranging from $1.63 \mu \mathrm{g} / \mathrm{g}$ to $25.69 \mu \mathrm{g} / \mathrm{g}$ with an average of $5.61 \mu \mathrm{g} / \mathrm{g}$ for $\mathrm{FB}_{1}$ and from $0.38 \mu \mathrm{g} / \mathrm{g}$ to $8.60 \mu \mathrm{g} / \mathrm{g}$ with an average of $1.86 \mu \mathrm{g} / \mathrm{g}$ for $\mathrm{FB}_{2}$. In terms of fumonisins, these high levels put the corn cultivated in São Paulo among the most contaminated in the world reported to date.
\end{abstract}

Key words: mycotoxins, fumonisins, Fusarium, corn.

\section{INTRODUCTION}

Corn is the most produced grain in Brazil and the one with the largest cultivation area. In São Paulo, the Instituto Agronômico de Campinas (IAC) and the Coordenadoria de Assistência Técnica Integral (CATI), both under the Secretaria de Agricultura e Abastecimento, Brazil, and the commercial seed producing companies have developed a partnership to test commercial maize cultivars in terms of productivity, resistance to diseases and adaptability to the maize growing areas of the state.

Corn is constantly exposed to toxigenic fungi (26). Several fungi species have been associated to corn, mainly the ones from the genera Fusarium, Aspergillus e Penicillium. This is a cause of concern because these same genera have species capable of producing a wide array of compounds shown to be toxic to man and animals (8).

Fumonsins are a group of mycotoxins produced mainly by Fusarium moniliforme and $F$. proliferatum and to a lesser extent by other species of the Liseola section. F. moniliforme is ubiquitous and can produce asymptomatic infections in corn
(6). Among the fumonsins characterized so far, $\mathrm{FA}_{1}, \mathrm{FA}_{2}, \mathrm{FA}_{3}$, $\mathrm{FB}_{1}, \mathrm{FB}_{2}, \mathrm{FB}_{3}, \mathrm{FB}_{4}, \mathrm{FC}_{1}, \mathrm{FC}_{3}, \mathrm{FC}_{4}, \mathrm{FAK}_{1}, \mathrm{FP}_{1}, \mathrm{FP}_{2}, \mathrm{FP}_{3}, \mathrm{FPH}_{1 \mathrm{a}}$ and $\mathrm{FH}_{1 \mathrm{~b}}(10,16,19), \mathrm{FB}_{1}$ is the most toxic and the most abundant comprising from 60 to $90 \%$ of the fumonsins found in lab cultures and corn samples $(10,16,23)$. It has been shown that $\mathrm{FB}_{1}$ causes leukoencephalomalacia in horses (ELEM) (15), pulmonary edema in swine (SPE) (11), brain hemorrhage in rabbits (2) and liver cancer in mice (5). Esophageal cancer in humans has been related to the presence of fumonsins in the diet of populations in China (25) and in South Africa (20).

In Brazil, ELEM has been reported in the states of Rio Grande do Sul, São Paulo, Santa Catarina, Minas Gerais (9), and Paraná $(19,24)$. Corn stored in silos in the states of Paraná, Mato Grosso do Sul and Goiás has shown to be contaminated with $\mathrm{FB}_{1}$ and $\mathrm{FB}_{2}$ (7). More information is needed about the possible presence of fumonisins in corn being cultivated in the country in order to allow the necessary measures to be taken by the government agencies involved with the production, regulation and control of foods and feeds.

The present work aimed to check for $\mathrm{FB}_{1}$ and $\mathrm{FB}_{2}$ in freshly harvested commercial cultivars corn planted in different locations of the state of São Paulo. The locations chosen

\footnotetext{
* Corresponding author. Mailing address: Departamento de Ciência de Alimentos, Faculdade de Engenharia de Alimentos, Universidade Estadual de Campinas, Caixa Postal 6121, CEP 13081-970, Campinas, SP, Brasil. E-mail: valente@ fea.unicamp.br
} 
belong to areas where corn constitutes an important commercial crop.

\section{MATERIALS AND METHODS}

Samples: Twenty three samples of corn corresponding to 19 commercial cultivars (Table 1) were harvested at the Experimental Stations of Capão Bonito, Ribeirão Preto and Votuporanga, belonging to the Agronomic Institute of Campinas. All ears were harvested in the two central rows of each cultivar plot. The kernels were shelled and combined. The samples were homogenized and reduced by either quartering or riffling to $500 \mathrm{~g}$. The samples were kept in plastic bags at $-18^{\circ} \mathrm{C}$ until analysis. The grain was ground to 20 mesh prior to analysis.
Fumonisins $B_{1}$ and $B_{2}$ standard solutions: Individual stock solutions of $\mathrm{FB}_{1}$ and $\mathrm{FB}_{2}$ (Sigma Chemical Company, St. Louis, $\mathrm{MO}$ ) were prepared dissolving $1 \mathrm{mg}$ in acetonitrile/water $(1+1)$ according to Visconti et al. (23). Working solutions were then prepared with concentrations of $50 \mu \mathrm{g} / \mathrm{ml}$ of $\mathrm{FB}_{1}$ and $\mathrm{FB}_{2}$, respectively. All standard solutions were kept in amber flasks at $-18^{\circ} \mathrm{C}$ when not in use.

Fumonisins determination: The determinations of fumonisins were conducted by HPLC with fluorescence detection according to Shephard et al. (17) with modifications as described by Camargos et al. (3).

Analytical quality control: Samples were analyzed in batches of 10 and each batch included a recovery test. Duplicates were analyzed in different days and the results were corrected for the recovery of the batch. Relative standard

Table 1. Agronomic characteristics of some corn commercial cultivars planted during the growing season of $97 / 98$ in the Experimental Stations of Capão Bonito, Ribeirão Preto and Votuporanga, from the Agronomic Institute of Campinas, São Paulo, Brazil.

\begin{tabular}{|c|c|c|c|c|}
\hline Experimental Station & Cultivars & Type of cross & Endosperm type & Cycle lenght \\
\hline \multirow[t]{7}{*}{ Capão Bonito } & 1 & double & yellow semi dent & normal \\
\hline & 2 & double & yellow dent & normal \\
\hline & 3 & triple & yellow semi dent & precocious \\
\hline & 4 & double & yellow semi flint & normal \\
\hline & 5 & triple & orange semi flint & precocious \\
\hline & 6 & triple & orange flint & precocious \\
\hline & 7 & single & orange flint & precocious \\
\hline \multirow[t]{7}{*}{ Ribeirão Preto } & 8 & double & yellow dent & normal \\
\hline & 2 & double & yellow dent & normal \\
\hline & 5 & triple & orange semi flint & precocious \\
\hline & 9 & variety & yellow semi dent & precocious \\
\hline & 10 & triple & orange semi flint & normal \\
\hline & 11 & double & yellow semi dent & precocious \\
\hline & 12 & single & orange semi dent & precocious \\
\hline \multirow[t]{9}{*}{ Votuporanga } & 13 & double & yellow semi dent & normal \\
\hline & 14 & double & orange semi flint & precocious \\
\hline & 15 & double & yellow semi dent & normal \\
\hline & 1 & double & yellow flint & super precocious \\
\hline & 16 & double & yellow semi dent & precocious \\
\hline & 17 & double & orange semi dent & precocious \\
\hline & 18 & single & orange semi flint & precocious \\
\hline & 19 & triple & yellow semi dent & precocious \\
\hline & 11 & double & yellow semi dent & precocious \\
\hline
\end{tabular}

Normal cycle - masculine flowering around 70 days after planting; precocious cycle - around 65 days; super precocious - under 60 days. 
Table 2. Levels of fumonisins in corn from the cultivars grown in the Experimental Stations of Capão Bonito, Ribeirão Preto and Votuporanga, São Paulo, Brazil, during the 97/98 crop.

\begin{tabular}{|c|c|c|c|}
\hline \multirow{2}{*}{ Experimental Station } & \multirow{2}{*}{ Cultivars } & \multicolumn{2}{|c|}{ Fumonisins $(\mu \mathrm{g} / \mathrm{g})$} \\
\hline & & $\mathrm{B}_{1}$ & $\mathrm{~B}_{2}$ \\
\hline \multirow[t]{7}{*}{ Capão Bonito } & 1 & 9.49 & 2.76 \\
\hline & 2 & 6.82 & 2.50 \\
\hline & 3 & 3.37 & 0.65 \\
\hline & 4 & 1.78 & 0.38 \\
\hline & 5 & 1.63 & 0.45 \\
\hline & 6 & 4.48 & 1.17 \\
\hline & 7 & 8.00 & 2.73 \\
\hline \multirow[t]{7}{*}{ Ribeirão Preto } & 8 & 12.25 & 3.68 \\
\hline & 2 & 7.18 & 2.09 \\
\hline & 5 & 2.57 & 1.01 \\
\hline & 9 & 25.69 & 8.60 \\
\hline & 10 & 8.33 & 2.88 \\
\hline & 11 & 5.28 & 2.00 \\
\hline & 12 & 2.76 & 1.02 \\
\hline \multirow[t]{10}{*}{ Votuporanga } & 13 & 2.40 & 0.89 \\
\hline & 14 & 4.13 & 1.62 \\
\hline & 15 & 4.82 & 1.90 \\
\hline & 1 & 4.58 & 1.37 \\
\hline & 16 & 3.83 & 1.89 \\
\hline & 17 & 2.31 & 0.56 \\
\hline & 18 & 1.86 & 0.82 \\
\hline & 19 & 2.85 & 0.69 \\
\hline & 11 & 2.60 & 1.08 \\
\hline & Average & 5.61 & 1.86 \\
\hline
\end{tabular}

The results represent the average of two determinations

deviations between duplicates were considered acceptable up to $30 \%$.

\section{RESULTS AND DISCUSSION}

Analytical quality control: the standard curves for $\mathrm{FB}_{1}$ and $\mathrm{FB}_{2}$ were linear in the concentrations from 0.02 to $10 \mu \mathrm{g} /$ $\mathrm{g}$ and from 0.04 to $10 \mu \mathrm{g} / \mathrm{g}$, respectively. The limits of detection were $0.02 \mu \mathrm{g} / \mathrm{g}$ for $\mathrm{FB}_{1}$ and $0.04 \mu \mathrm{g} / \mathrm{g}$ for $\mathrm{FB}_{2}$. The average recovery and the relative standard deviation were $92 \%$ and $0.6 \%$ for $\mathrm{FB}_{1}$ and $72 \%$ and $2.2 \%$ for $\mathrm{FB}_{2}$, respectively.

Incidence of fumonisins in freshly harvested corn: All samples analyzed contained $\mathrm{FB}_{1}$ and $\mathrm{FB}_{2}$ (Table 2). The ratio of $\mathrm{FB}_{2} / \mathrm{FB}_{1}$ ranged from 0.21 to 0.44 showing $\mathrm{FB}_{1}$ by far prevailing over $\mathrm{FB}_{2} . \mathrm{FB}_{1}$ predominating over $\mathrm{FB}_{2}$ have been more frequently reported in the literature and are considered more typical for these toxins $(10,16)$. The highest levels of contamination were found in Ribeirão Preto, both for $\mathrm{FB}_{1}$ and $\mathrm{FB}_{2}$.

All samples had $\mathrm{FB}_{1}$ above $1.0 \mu \mathrm{g} / \mathrm{g}$ and $35 \%$ had $\mathrm{FB}_{1}$ above $5.0 \mu \mathrm{g} / \mathrm{g}$. According to the Mycotoxin Committee of American Association of Veterinary Diagnosticians this is a level of concern for animal feed. Levels below $5.0 \mu \mathrm{g} / \mathrm{g}$ are recommended for horses, below $10.0 \mu \mathrm{g} / \mathrm{g}$ for swine and $50.0 \mu \mathrm{g} / \mathrm{g}$ for cattle and chickens (13). Levels above $10.0 \mu \mathrm{g} / \mathrm{g}$ may cause ELEM in horses (14), but levels below $7.7 \mu \mathrm{g} / \mathrm{g}$ $\mathrm{FB}_{1}$ have been recorded as causing ELEM (21). Ross et al. (15) reported SPE cases when the feed used contained $10 \mu \mathrm{g} / \mathrm{g}$ de $\mathrm{FB}_{1}$. Sydenham et al.(19) described cases of swine, fowl and rabbits suspected of mycotoxicoses after ingestion of feed contaminated with $7 \mu \mathrm{g} / \mathrm{g}$ de $\mathrm{FB}_{1}$. Bane et al. (1), however, found levels of $\mathrm{FB}_{1}+\mathrm{FB}_{2}$ higher than $31 \mu \mathrm{g} / \mathrm{g}$ in cases of swine mycotoxicoses. At least seven samples analyzed in the present work had levels of $\mathrm{FB}_{1}$ and $\mathrm{FB}_{2}$ within ranges not recommended for animal feed (Table 2).

The levels of contamination found in the maize examined in the present work (Table 2) compare with those reported in Transkei, South Africa, in areas where the high incidence of esophageal cancer have been correlated with the presence of the toxin in corn used as food $\left(0.45-18.90 \mu \mathrm{g} / \mathrm{g}\right.$ for $\mathrm{FB}_{1}$ e de $0.15-6.75 \mu \mathrm{g} / \mathrm{g}$ for $\mathrm{FB}_{2}$ ) (20). Linxian, province of China, is considered an area of high risk for esophageal cancer. The levels of $\mathrm{FB}_{1}$ and $\mathrm{FB}_{2}$ in the corn consumed by the population ranges from 0.19 to $2.96 \mu \mathrm{g} / \mathrm{g}$ and from 0.30 to $0.55 \mu \mathrm{g} / \mathrm{g}$, respectively (25). Shephard et al. (18) reviewed the data on the contamination of corn by fumonsins and the upper value and the mean value of the present survey is higher than the results of the surveys reported from Benin, Canada, China, Croatia, Gambia, Italy, Nepal, Portugal, Romania, South Africa and USA. The data reported in the present work clearly indicates a threat to human health for frequent consumers of corn products and strongly suggests the subject should be further studied to assess the risk the consumption of corn products may represent for the public health.

In this study, high levels of contamination have been found in all types of cultivars (variety, single, double, and triple cross hybrids), as well as all types of vegetative cycle (normal precocious and super precocious) and types of endosperm (flint, dent, semi flint and semi dent) (Table 1 and 2) although no statistic calculation was attempted due to the low number of samples examined.

The possible geographical nature of the contamination of corn by fumonsins has been pointed out. Visconti (22) examined samples of corn genotypes grown in several parts of the world. He found that four main groups could be recognized in terms 
of fumonisins contamination level: Eastern Europe (Poland, Romania and Croatia) would be the group with lowest contamination, Western Europe (Italy and Portugal) with slightly higher contamination, Africa (Benin and Zambia) with still higher contamination and finally Argentina with the highest levels of contamination. The levels of fumonisins found in the present work are comparable with the levels reported for Argentinian freshly harvested corn $(4,12)$ and indicate that high levels of contamination by fumonisins in corn might be a South American problem or at least, a problem for the south tip of the continent.

\section{ACKNOWLEDGEMENTS}

The authors gratefully acknowledge the support of the Fundação de Amparo à Pesquisa do Estado de São Paulo (FAPESP), Research Grant \# 95/03392-7, and a graduate scholarship for the first author from the Conselho Nacional de Pesquisas (CNPq).

\section{RESUMO}

\section{Fumonisinas em cultivares de milho no Estado de São Paulo}

Vinte e três amostras, representando 19 cultivares de milho com diferentes tipos de germoplasma, de endosperma e ciclo vegetativo, foram avaliadas quanto ao teor de fumonisinas em três Estações Experimentais do Instituto Agronômico (Capão Bonito, Ribeirão Preto e Votuporanga) em São Paulo, Brasil, durante a safra de 97/98. Todos os cultivares analisados estavam contaminados com fumonisinas em níveis que variaram de $1.63 \mu \mathrm{g} / \mathrm{g}$ a $25.69 \mu \mathrm{g} / \mathrm{g}$ e uma média de $5.61 \mu \mathrm{g} / \mathrm{g} \mathrm{FB}$ e de $0.38 \mu \mathrm{g} / \mathrm{g}$ a $8.60 \mu \mathrm{g} / \mathrm{g}$ e uma média de $1.86 \mu \mathrm{g} / \mathrm{g} \mathrm{FB}_{2}$. Estes níveis tão elevados colocam o milho cultivado no Estado de São Paulo entre os mais contaminados do mundo em termos de fumonisinas.

Palavras-chave: Micotoxinas, fumonisinas, Fusarium, milho.

\section{REFERENCES}

1. Bane, D. P.; Neumann, E. J.; Hall, W. F.; Harlin, K. S.; Slife, R. L. N. Relationship between fumonsins contamination of feed and mystery swine disease. Mycopathologia, 117: 121-124, 1992.

2. Bucci, T.; Hansen, D. K.; Laborde, J. B. Leukoencephalomalacia and hemorrhage in the brain of rabbits gavaged with mycotoxin fumonisin $B_{1}$. Natural Toxin, 4:51-52, 1996.

3. Camargos, S. M.; Machinski Jr, M.; Valente Soares, L. M. Otimização de métodos para determinação de fumonisinas $\mathrm{B}_{1}$ e $\mathrm{B}_{2}$ em milho. Rev. Inst. Adolfo Lutz, 58:71-79, 1999.

4. Chulze, S.N.; Ramirez, M.L.; Farnochi, M.C.; Pascale, M.; Visconti,A.; March, G. Fusarium and fumonsins occurrence in Argentinian corn at different ear maturity stages. J. Agric. Food Chem. 44: 2797- 2801, 1996.

5. Gelderblom, W. C. A.; Kriek, N. P. J., Marasas, W. F. O., Thiel, P. G. Toxicity and carcinogenicity of the Fusarium moniliforme metabolite, fumonisin $\mathrm{B}_{1}$, in rats. Carcinogenesis, 12: 1247-1251, 1991.
6. Headrick, J. M.; Pataky, J. K. Maternal influence on the resistance of sweet corn lines to kernel infection by Fusarium moniliforme. Phytopathol., 81: 268-274, 1991.

7. Hirooka, E. Y.; Yamagushi, M. M.; Aoyama, S.; Sugiura, Y.; Ueno, Y. The natural occurrence of fumonisins in Brazilian corn kernels. Food Add. Contam., 13:173-183, 1996.

8. Marasas, W. F. O. Medical relevance of mycotoxins in southern Africa. Microbiol. Alimen. Nutr., 6: 1-5, 1988.

9. Meireles, M. C. A.; Corrêa, B.; Fischman, O.; Gambale, W.; Paula, C. R.; Chacon- Reche, N. O.; Zozzi, C. R. Mycoflora of the toxic feeds associated with equine leukoencephalomalacia (ELEM) outbreaks in Brazil. Mycopathologia. 27:183-188, 1994.

10. Musser, S.M.; Plattner, R.D. Fumonsin composition in cultures of Fusarium moniliforme, Fusarium proliferatum, and Fusarium nygami. J. Agric. Food Chem., 45: 1169-1173, 1997.

11. Osweiler, G. D.; Ross, P. F.; Wilson, T. M., Nelson, P. E.; Witte, S. T.; Carson, T. L., Rice, L. G., Nelson, H. A. Characterization of an epizootic of pulmonary edema in swine associated with fumonisin in corn screenings. J. Vet. Diag. Invest., 4: 53-59, 1992.

12. Ramirez, M.L.; Pascale, M.; Chulze, S.; Reynoso, M.M.; March, G.; Visconti, A. Natural occurrence of fumonsins and their correlation to Fusarium contamination in commercial corn hybrids growth in Argentina. Mycopathologia, 135: 29-34, 1996.

13. Riley, R. T.; Norred, W. P., Bacon, C. W. Fungal toxins in foods: recent concerns. Ann. Rev. Nutr., 13: 167-189, 1993.

14. Ross, P. F.; Rice, L. G.; Osweiler, G. D.; Nelson, P. E.; Richard, J. L.; Wilson, T. M.; Riley, R. T. A review and update of animal toxicoses associated with fumonisin-contaminated feeds and production of fumonisins by Fusarium isolates. Mycopathologia, 117: 109-114, 1992.

15. Ross, P. F.; Rice, L. G.; Plattner, R. D., Osweiler, G. D.; Wilson, T. M.; Owens, D. L.; Nelson, H. A.; Richard, J. L. Concentrations of fumonisin $\mathrm{B}_{1}$ in feeds associated with animal health problems. Mycopathologia, 114:129-135, 1991.

16. Seo, J.-A.; Lee, Y.-W. Natural occurrence of the $\mathrm{C}$ series of fumonsins in moldy corn. Appl. Environ. Microbiol., 65: 1331-1334, 1999.

17. Shephard, G. S.; Sydenham, E. W.; Thiel, P. G., Gelderblom, W. C. A. Quantitative determination of fumonisins $\mathrm{B}_{1}$ and $\mathrm{B}_{2}$ by high-performance liquid chromatography with fluorescence detection. J. Liq. Chrom., 13: 2077 2087, 1990.

18. Shephard, G.S.; Thiel, P.G.; Stockenstrom, S.; Sydenham, E.W. Worldwide survey of fumonsin contamination of corn and corn-based products. J. AOAC Int., 79: 671- 687, 1996.

19. Sydenham, E. W.; Marasas, W. F. O.; Shephard, G. S.; Thiel, P. G.; Hirooka, E. Y. Fumonisin concentrations in Brazilian feeds associated with field outbreaks of confirmed and suspected animal mycotoxicoses. J. Agric. Food Chem., 40: 994-997, 1992.

20. Sydenham, E. W.; Thiel, P. G.; Marasas, W. F. O.; Shephard, G. S.; Van Schalkwyk, D. J.; Koch, K. R. Natural occurrence of some Fusarium mycotoxins in corn from low and high oesophageal cancer prevalence areas of the Transkey, Southern Africa. J. Agric. Food Chem., 38: 1900-1903, 1990.

21. Thiel, P. G.; Marasas, W. F. O.; Sydenham, E. W.; Shephard, G. S.; Gelderblom, W. C. A.; Nieuwenhuis, J. J. Survey of fumonisin production by Fusarium species. App. Environ. Microbiol., 57, n. 4, p. 1089-1093, Apr. 1991.

22. Visconti, A. Fumonisins in maize genotypes grown in various geographic areas. In: Jackson, L.S.; De Vries, J.W.; Bullerman, L.B. (eds.) Fumonisins in food. Plenum Press, New York, 1995, 193 - 204.

23. Visconti, A.; Doko, M.B.; Bottalico, C.; Schurer, B.; Boenke, A. Stability of fumonsins in solution. Food Add. Contam., 11: 427-431, 1994.

24. Yamagushi, M. M.; Hirooka, E. Y.; Shibata, T. M. M.; Hassegawa, R. H.; Aoyama, S., Sugiura, T.; Ueno, Y. Fumonisinas em milho no Estado do Paraná. VII Encontro Nacional de Micotoxinas, São Paulo, 1992, p. 27.

25. Yoshizawa, T.; Yamashita, A.; Luo, Y. Fumonisin occurrence in corn from high- and low-risk areas for human esophageal cancer in China. Appl. Environ. Microbiol., 60: 1626-1629, 1994.

26. Zummo, N.; Scott, G. E. Interaction of Fusarium moniliforme and Aspergillus flavus on kernel infection and aflatoxin contamination in maize ears. Plant Dis., 76: 771-773, 1992. 